\title{
FOUR CONTEMPORARY ILOKANO POEMS IN TRANSLATION
}

\author{
Junley L. Lazaga \\ University of the Philippines Baguio \\ jllazaga@up.edu.ph
}

\begin{abstract}
About the Author/Translator
Junley L. Lazaga received both his Bachelor's and Master's degrees in Language and Literature from the University of the Philippines Baguio where he served as chairperson of the Department of Language, Literature and the Arts from 2013-2017. Part of his Master's thesis spawned a collection of Ilokano poems with Filipino translations which has been published by the Komisyon sa Wikang Filipino and the National Commission for Culture and the Arts in 2015 as Dandaniw Ilokano: mga tulang Ilokano, 1621-2014. He is also the co-editor and translator of a collection of poems of Alegria Tan Visaya, titled Sapsapo/Balm: Poems in Ilokano and English, published in 2016 by Nakem Conferences and Undertow Books. He was a recipient of the 2011 UP Baguio Golden Jubilee Award for Creative Work in recognition of his produced work in poetry in Ilokano, Filipino and English, and translations in Filipino and English, and was named Translator of the Year in 2016 by the Baguio Midland Courier.
\end{abstract}

\section{About the Authors and Their Poems}

Roy V. Aragon (born 1968, Dupax del Norte, Nueva Vizcaya) is a fictionist and poet whose works both in Ilokano and Filipino have won awards such as those from the Reynaldo F. Antonio Awards for Iloko Literature (RFAAFIL), Governor Roque Ablan Awards for Iluko Literature (GRAAFIL), Constancia V. Lansangan Literary Awards (COVLLA), the Don Carlos Palanca Memorial Awards for Literature. He was also a recipient of a grant from the National Commission for Culture and the Arts (NCCA) for the translation of the anthology of short stories by Ilocano veteran writer Juan SP Hidalgo, Jr. He was a fellow for Ilocano fiction at the $26^{\text {th }}$ UP National Writers' Workshop (1996), fellow for poetry at the $9^{\text {th }}$ Lamiraw Literary Workshop (2012), and a delegate and panelist at the Taboan Philippine International Writers' Festival (2011). He is currently a member of the board of directors of the national association of Ilokano writers, the Gunglo dagiti Mannurat nga Ilokano iti Filipinas (GUMIL-Filipinas), and resident panelist of the annual Ilokano Writers' Workshop, Pasnaan. His first poetry collection, the first Ilokano poetry e-book, Napili ken Saan a Napili a Dandaniw ken Dadduma Pay a Riknakem (Selected and Not Selected Poems and Other Musings), was released in 20oo. His poetry anthology, Bagi: dandaniw (Body: poems) was published by Saniata Publications in 
2016. "Awis ti Hulio" is included in the anthology of Ilokano poems, Kastoy nga Imbunubonmi Dagiti Balikas: Antolohia Dagiti Daniw Iti Iluko (2010).

Mighty C. Rasing (born 1982, San Manuel, Isabela) writes poetry and short fiction in Ilokano, and essays in Ilokano and English: He is now based in Nashville, Tennessee, and working as the Program Development Director of Young Peoples' Ministries, an agency of the United Methodist Church. He graduated in 2003 with a BA degree in Political Science from the University of the Philippines Diliman. He is also a member of GUMIL Metro Manila and GUMIL Filipinas. "Ipapanaw iti Maikasangapulo a Balay" was first published in Bannawag, 2 January 2006; it is also included in Kastoy nga Imbunubonmi Dagiti Balikas: Antolohia Dagiti Daniw iti Iluko (2010).

Ariel S. Tabag (born 1978, Sta. Teresita, Cagayan) is an award-winning Ilokano fictionist and poet, literary editor, and translator. He holds an AB degree major in Philosophy which he obtained in 1999 from Our Lady of the Angels Seminary in Novaliches, Quezon City. Among book titles to his name are Karapote: Antolohia Dagiti 13 a Nasuerte a Sarita (2011), a collection of his short stories, Panangarakup iti Ipus ti Layap (2016), an anthology of his poems, Ay, Ni Reberen! (2013), his short novel, and his novel Kapessat ti Bagis (2016). He was a fellow at the 41st UP National Writers' Workshop (2002), and delegate to the 2010 Taboan Philippine International Literary Festival and 6th Philippine International Literary Festival 2015. He edits the poetry section of Bannawag, and is currently the Secretary-General of GUMIL Filipinas. He is also the winner of the National Commission for Culture and the Arts' 2013 Writer's Prize for Ilocano Novel for his novel, Kabessat Ti Bagis and a grantee of the National Book Development Board's National Book Development Trust Fund 2013 for his novel in Ilocano, Panangsapul iti Puraw a Kabalio. "Superhighway," was first published in Bannawag, 16 March 2009, with the title "Ti Nagbaetan ti Baybay ken Bullalayaw (Wenno ti Kalsada a Nangusat iti Awaymi)" (Between the Sea and the Rainbow (Or the Road that Raided Our Barrio)). It was later published in Kastoy nga Imbunubonmi Dagiti Balikas: Antolohia Dagiti Daniw Iti Iluko (2010), together with "(No) Maysaakon A Sangsangaili."

Kritika Kultura 28 (2017): -395

(C) Ateneo de Manila University

<http://journals.ateneo.edu/ojs/kk/> 
1.

Themes of estrangement, displacement, and diaspora permeate contemporary Ilokano poetry, as according to Aurelio Solver Agcaoili, citing specific poems by Roy Aragon, among others, that: "[i]n the poems are the difficult experiences of leaving home, of becoming a stranger in a new place, and [...] of becoming a stranger in an old place, in the same country, in your country" (6). The four poems by three Ilokano writers which comprise this suite articulate different forms of estrangement as a result, symptom, or cause of displacement either as in the physical movement in diaspora or the emotional and the metaphysical, or both. For Agcaoili:

To be "displaced" - to be in another place, to be in another ground, is a form of disease," a trope of instability, illness, sickness, or malady. The experience of displacement as "dis-ease" marks the poetic sensibilities of those "strangers in a new land." But it marks the sensibilities as well of those "strangers in their own land" as is the case of the poets of alienation like Aragon [...]. (6-7)

Referring specifically to Aragon's poem, "nalipatannakon a seggaan ti agur-uray a pagpigadan" (translated by Agcaoili as "the doormat has forgotten to be excited of me"), Agcaoili notes that:

Aragon [...] ups the ante of the desolation of estrangement and the impossibility of coming back-of homing - in the allegory of the doormat [...] He writes of the domestic references to a blissful life through the word of that storyteller whose name we do not know, but whose voice is clear as an "i, the self": "the doormat has forgotten to be excited of me,/ the mosquitoes and the dragonflies have taken their residence there./ no longer i feel the bed, table, and the earthen stove missing me." (7)

How does the Ilokano poet put into words his thoughts in relation to an experience of alienation, or of other emotions that bring about a seemingly chronic sense of detachment from home or what used to be home? The outcome is, in the poem, an Ilokano persona giving expression to otherwise mute heartaches that are a potential source of anguish. The Ilokano persona-and by Ilokano, I mean someone who happens to be a speaker of the Ilokano language-would be a veritable speaker for the poets' embodiment of their wanting to understand these emotions. That is to say, that through the turns of expression and the nuances of words in Ilokano, poetic utterances are actually details of verisimilitude in Ilokano thought which are in Ilokano norms rather "best left unsaid." These are pulled back down the throat; they stay in the deepest chambers of the chest. And, so it seems, as in poetry: the persona talks to himself. No longer mute are these pains, nonetheless-no matter that it is done in the poetic quiet of the persona's voice. 
The poems "Superhighway" and "(No) Maysaakon a Sangsangaili" both by Ariel $\mathrm{S}$. Tabag, for example, are articulations in the lyrical voice. The voice we hear from the poem "Superhighway," for instance, comes from the traditional lyrical persona who, from his god-like position, makes sense of the whole picture he sees of the remarkable changes in his hometown and ties it up with the age-old theme of the irony of humanity which is mortality.

A slightly different lyrical technique is employed in "(No) Maysaakon a Sangsangaili," or "(If) I Have Become A Stranger." What we read-or hear-are the thoughts of the Ilokano who, in his return to his hometown, finds himself as a foreigner. But rather than being omniscient-i.e. able to see everything at once, able to make sense of the whole, and present a grand theme-he is subject to the gradually unfolding of the full picture before him. As he is identified by the townsfolk (of the transformed hometown) to the old and artifactual, he confirms his being foreign.

This "foreign-ness" is presented differently as a species of the complex of alienation in "Ipapanaw iti Maikasangapulo a Balay" (Leaving the Tenth House) by Mighty C. Rasing. Transportation-as movement, as the very beat of life itself-which is continuous, imperative, and apparently necessary, is a choice, or has become one. It has become banal; too ordinary, it does not come with grand announcements. And it is in its becoming mundane from which the very irony emerges.

It is not only the spatial that is involved in such themes, but also the temporal. We see the complexity of the interrelatedness of space, time, childhood, romance, longing, reminiscences, the actual sensation of taste, and otherwise mundane artefacts which are articulated with a type of displacement, alienation, or estrangement in the poem "Awis ti Hulio" (Invitation of July) by Roy V. Aragon. Exemplified here is Aragon's mastery of the Ilokano sensual: at the onset, the poem presents an invigorating aroma of freshly brewed coffee then proceeds to a recalling a variety of tropical fruits which ultimately results in the salivating sensation-in Ilokano alino, makapaalino-the climax of which is mango dipped in the Ilokano fish paste, bugguong. And who could not notice-whether positively or negatively - the smell of bugguong, this fish paste of the very Ilokano existence? All these neatly woven in the poetic framework of the piece to engage the reader (the Ilokano reader specially since the poems were originally written in Ilokano) in a dismantling of the complacency of oblivion, an unraveling of what may rather be kept in the old wooden trunk, in subtlety. The apostrophe results in, to a certain extent, estrangement. But, by whom and with whom-that should be left to be discovered in the poem (which the translation hopes to provide). 
2.

How would the aforementioned relationship between Ilokano speech and the poetic be provided with equivalence in translation? The Ilokano literary scholar and historian Dr. Marcelino A. Foronda Jr., in his brief note about the translation of the poems in his anthology of Ilokano poetry, relates that "[...] in many instances it [is] impossible to translate into English Ilokano terms or turns of expression" (17). He must have been referring to a similar problem I encountered, for instance in this suite, with the terms found in the titles: "ipapanaw" (Rasing), "awis" (Aragon), "maysaakon" and "sangsangaili" (Tabag), the phrase "sallukoban dagiti pan-aw" (Tabag, "Superhighway"), and the entire line "Addan iti lilidduokam ti gusod, addan iti barukongmo ti guyod" (Aragon). Some have one-word lexical equivalents as in ipapanaw ("leaving") and awis, ("invitation"), although semantic nuances would emerge at the level of discourse when the context of utterance comes into play.

In other cases, the morphosyntactic feature of Ilokano words-although indubitably untranslatable into single-words in English-may, however, still be rendered in English using one-to-one correspondence. For example, maysaakon translates in the context of "maysaakon a sangsangaili" as "I have become," i.e. "I have become a foreigner." Other words, however, are culturally loaded. Such is the case of sangsangaili. Sangaili, is usually visitor or guest, and by extension, foreigner, stranger; but, so is baniaga (cognate to the Tagalog banyaga) which is literally traveller, as foreign, and stranger may also be sabsabali (other). However, sangaili as a cultural lexeme involving the Ilokano's way of relating to an "other" who is welcomed as a visitor. While recognizing his otherness, the sangaili is treated as part of the family and, to an extent, the [Ilokano] community. Sangaili, if it truly derives from the contracted form of "maysa nga ili," literally "a town," also contains the concept of the person as a representation of his tribe or community, or at least his family. For in Gelade's dictionary, the entry for sangaili in page 582 refers back to ili in page 243, such that if an Ilokano travels to another town or is a guest at someone else's house, he is a sangaili. He thus considers himself and behaves as one, representing his entire community.

And, yes, the potential of a multitude of meaning and the texture that this multiplicity of semiotic and semantic levels can bring, is lost in translation. But even contextual meaning is not singular; nor is it merely a binary or simply dyadic. Metaphors could refer further back to the origins of our language. A poetic utterance may not merely be an allusion exclusively coherent within the poem in itself; it is neither just the poet's idiosyncratic symbolism nor simply an allegory. Still, it may be all of these at the same time; besides, how is a poetic unit like this supposed to be translated if not through the translator's choice of which ones to let go of, in order to salvage even just a few and ultimately, the essential? One of these

Kritika Kultura 28 (2017): -395

(C) Ateneo de Manila University

$<$ http://journals.ateneo.edu/ojs/kk/> 
"unsalvageable" features of the original which are inevitably lost in translation, for instance a poem in Ilokano into English, of which Foronda's experience is a good example of: "[...] the sonorousness and the musicality of the lines-which make listening to the recitation of Ilokano poetry such a pleasurable experience [...] and what results is somewhat dry and flat" (17-18).

Additionally, for Professor Peter Newmark:

Translation is a craft consisting in the attempt to replace a written message and/or statement in one language by the same message and/or statement in another language. Each exercise involves some kind of loss of meaning, due to a number of factors. It provokes a continuous tension, a dialectic, an argument based on the claims of each language. (7)

Central to translators' code are the principles of clarity and faithfulness to the original. But what must not also be forgotten is, to borrow from Newmark, "the primacy of feeling" (161). As Newmark says,

The persuasive element or passage in a text must be treated vigorously and with some imagination by the translator, since it is intended to rouse feeling, if not action, in his reader. Usually it is more colloquial in style than the informative and the expressive element. Syntactically, languages appear to differ far more widely when used to express feelings and give orders and instructions than ti make statements. (161)

Poetry, as rhetorical, aims to directly appeal to the emotions. In its brevity, it is permeated by deeply affective rhetoric. To successfully translate this aspect, Peter Newmark notes the primacy of feeling in translating not only literary texts but also those with persuasive element or passage which "...must be treated vigorously and with some imagination by the translator, since it is intended to rouse feeling, if not action, in his reader" (161). This very problem is underscored in translating every single word of a poem.

Foronda opted to "[r]ather than use phrases to 'explain' the terms, the Ilokano words were retained in English translation with corresponding notes in the glossary necessary for understanding the idea conveyed." However, in my translations in English, I chose to contend with the necessary evil, so to speak, of rendering in the closest equivalent and accept that nuances are lost in translation. On the other hand, I resorted to this means of translation (what Newmark calls labeling) with native terms, even if they have popular, accepted, or standard English "equivalents" or American English approximations. 
3.

The retaining of Ilokano words in the translated text is limited only to (a) native terms of cuisine and (b) names of flora, which may be generalized into one category of terms associated or relating to food. And such units are only retained if they render additional "flavor" of the "native" or the source culture. Notice, however, that pagay is translated as the standard approximation, "rice plant," and pan-aw is translated by means of the more popular borrowed word from Spanish, cogon. The approximation in the noun phrase, "rice plant," I think, already gives a signal of the foreign, and hence a "different" flavor is given. The case of "cogon grass" is similarly casted-that while cogon may still be totally foreign to some readers, "grass" is assistive.

For the words that were retained, at least two realities are possible: (a) these remain totally incomprehensible as words, and (b) they provide local color and provide balance to a translation that has relied mostly in idiomatic rendering, both assuming forms of defamiliarization. Such is the case of bugguong.

bugguong. A kind of preserved fish used to season food. The fish (any kind, but more especially ípon, bilís \& munámon) is first salted (one part of salt to 2 parts of fish and water), thoroughly kneaded, and then let to ferment in earthen jars. Sometimes, before it is salted, the fish is kept for a couple of days until it gets spoiled. It is used by Ilokanos to season vegetable dishes. It is often eaten raw with a dash of kalamansi juice or mixed with fresh tomatoes and sliced onions. (Gelade 139)

Bugguong may be acceptable as "fish paste" but should still be bugguong since not all bugguong are made of, literally, just fish. This is captured in another dictionary:

Fish paste; shrimp paste; fish sauce; var. bagguong, baguong; also, specific: bugguonga-dilis, anchovies; bugguong-a-munamon, anchovies (Philippine anchovy); bugguonga-padas, ziganid fry; bugguong-nga-aramang, shrimp, or soft-shelled shrimp. (Agcaoili 421)

The following can also be added to the list: bugguong nga ipon, a kind of fish; bugguong a tirem, oyster (which, definitely, cannot be oyster sauce).

The dilemma of whether or not to provide footnotes or endnotes for the glosses may only be a privilege for a book-length work of translation. Yet another option is a glossary in an essay form which constitute a translator's note, or as part thereof.

The fruits in the poem "Awis ti Hulio" perform individual and collective roles which are coherent to the mood, tone, and overall effect of the text. As foreign and 
incomprehensible words, they serve as devices that result in the defamiliarizing effect. Rendering them in the approximated names in English might give a different effect than the effects of sensation associated with appetite which is articulated with memory, temporal displacement, longing, and remembering. Besides, translating bugnay, for example, as black berries, might cause confusion with other "black berries" and blackberries. While it may be known in a variety of equivalents in English as salamander tree, salamander-boom, currant tree, Herbert river cherry, Queensland cherry, (Agcaoili, 2012, 387), in Ilokano, as in other Northern Philippine languages, it is bugnay: "Antidesma bunius (L.) Spreng. A dioecious, euphorbiaceous tree with entire leaves and ovoid, fleshy, red, acid, edible fruits" (Gelade 1993, 139); "Antidesma pentandrum (Blco.) Merr. var. pentandrum Euphorbiaceae" (Madulid 2001, 168); var. Ilokano bignay, also Tagalog bignay (Agcaoili 2012, 387).

The case of bugnay is similar to lomboy: variation of lungboy (Gelade 1993, 366); "the jambool or Java plum, Eugenia jambolana" (Gelade, 1993, 387); "Syzygium cumini (L.) Skeels Myrtaceae" (Madulid 2001, 436). In Tagalog what is also lomboy in some districts is more popularly known in Filipino as duhat. Trinidad Pardo de Tavera described the fruit of the mature lomboy, "of a violet color so dark it looks black, it is edible and very popular in the Philippines, although regarded as a regular fruit, does not appear in device tables. Some it are harmful, but, in reality, is a fruit of easy digestion," as follows

El fruto del lomboy maduro, de un color violèta tan obscuro que parece negro, es comestible y muy apreciado en Filipinas, aunque, considerado como una fruta ordinaria, no aparece en las mesas de aparato. Algunos la suponen dañosa, pero, en realidad, es una fruta de fácil digestión. (Pardo de Tavera 2000, 309)

While dippig - the banana variety known in Tagalog as saba, a favorite ingredient for the halo-halo or which can stand on its own in saba con yelo (with ice), or even without the ice for Ilokanos, kinalti (sweetened by means of boiling with sugar) - is a term indigenous to the land of many banana varieties, both papaya (English common name: papaya, papaw) and sarguelas (Tagalog common name: siniguwelas) are not although these have taken root deeply into the Ilokano land and language.

dippig

A variety of thick-skinned, small, yellow banana; the variety compressa. Blanco of Musa sapientum. L. (Gelade 1993, 191).

Kritika Kultura 28 (2017): -395

(C) Ateneo de Manila University

<http://journals.ateneo.edu/ojs/kk/> 
Saba banana; cardaba; sweet plantain; compact banana; papaya banana; cooking banana; a variety of banana used for turon, for sweets cooked with coconut milk, for viands, or for the making of ketchup (Agcaoili 2012, 539).

papaya

The word is actually borrowed from the Spanish papaya, Carica papaya (Gelade 1993, 469).

Carica papaya L. Caricaceae (Madulid 2001, 547).

sarguelas

From the Spanish ciruela, the Spanish plum; also siniguelas (Gelade, 1993, 592). Spondias purpurea L. Anacardiaceae (Madulid 2001, 647).

Red mombin; purple mombin; Spanish plum; hog plum; scarlet plum; red plum; synonym: siniguelas, sirguela, from the Spanish cirguela (Agcaoili 2012, 1508).

The mansanita, too, has been indigenized in Ilokano as the word itself shows. It has been rooted deeply into the Ilokano memory of childhood as well.

manzanita

The Spanish manzanita, a kind of small apple (Gelade, 1993, 398). Muntingia calabura L. Elaeocarpaceae (Madulid, 2001, 496). Variation: mansanita; also aratilis; Tagalog aratiles. English common name: Jujube fruit (Pardo de Tavera 2000, 60).

Bear grape; muntingia; Jamaican cherry; Panama berry; Singapore cherry; Strawberry tree; Indian jujube; Malay jujube; Indian plum; saraysa or saraisa; cotton candy berry; alabura; a small tree that yeilds round, sweet, and plum-like fruit (Agcaoili 2012, 1129).

A generic name for a shrub that bears "little apple-like" (from the Spanish manzana, apple; manzanita, little-apple) sweet plum-like fruits.

The small fruit is known commonly as manzanitas has an agreeable taste, although ordinarily offered for sale before they are quite ripe.

... A shrub, with hooked thorns, leaves alternate, petiolate, coriaceous, entire, 3-nerved, 2 thorny stipules, one of them crooked. Flowers small, greeninsh, auxillary. (Pardo de Tavera 200o, 60)

One will miss the strong Ilokano flavor in the dinengdeng, and, worse, may be confused with pinakbet, if it were translated as "vegetable stew." Perhaps, suggestive of the very nature of dish naming in Ilokano, Ilokano dictionaries commonly do not include entries for dinengdeng and pinakbet. One has to look for dengdeng and kebbet instead. Dengdeng, is the common way to cook, the Ilokano way: by boiling.

deñgdéñg. dineñgdéñg. A dish consisting of fish or vegetables or both cooked in water, seasoned with salt and sometimes with onions, piás, etc., and served with their juice. The commonest ingredients are vegetables and boggóóñg. (Iloko-English Dictionary 1956, 89)

Kritika Kultura 28 (2017): -395 
dengdéng

dinengdéng. A vegetable dish cooked in a generous amount of water, seasoned with salted fish, roasted fish, tomatoes, onions, ginger, garlic and other ingredients. Also called inabráw.

dengdengén, agdengdéng. To cook a vegetable dish.

(Gelade 184)

4.

There are, however, overlaps. Mostly, these are the inedible items. I consider angalo (in "Superhighway") and colossus as overlaps; hence, "dagiti angalo a pasdek" is rendered as "colossal buildings." On the other hand, pasdek is a more generic term for physical structure or infrastructure, and in a sense possesses a polysemic feature as it is used in the poem. That is, it could mean any and all types of erected structures. However, I rendered it as "building" mainly because I do not feel the poetic effect that pasdek has in infrastructure. Yet, on another note, the involvement of uong (mushroom) in the same stanza that pasdek is used may be read as suggesting an image of a shelter, hence home, and therefore building.

Whether a universal myth or an adopted myth by the Ilokano, or whoever had it first, gold at the "sakaanan ti bullalayaw" (in "Superhighway") and pot of gold at the foot of the rainbow or gold at the end of the rainbow are overlaps. Although "apagkirem" ("Superhighway") (from kirem, wink, blink) usually involves both eyes, since it is associated with kidem (conjugated as agkidem, to close both eyes), its English equivalent-and thus, overlap-is "blink of an eye" (with dialectical variation such as "bat of an eye").

As for lakasa, I would have chosen chest which will lend multiplicity of meaningincluding a perfectly appealing image of the front surface of the body either the persona's or his referents' which would yield a connotation of the heart, etc.-but I favored "the old wooden trunk" to bring it closer to the original since pointing at the lakasa clearly does not suggest the act of pointing at the breast or the heart if it were: I told them where I am to go and they pointed at the chest:// Here I found traces of the past and my home.

Additionally, I think I could play with an image of a persona asking the people in his hometown where home is, and get the following for an answer: the people pointing to their chests/breasts/hearts, and so on. Conversely, I do not see such 
an image suggested in the poem. The play of word with chest, or even trunk, in English does not have an overlap in the Ilokano use of lakasa:

lakasa (Sp. la casa). Chest, trunk (sometimes called baul), box (used for keeping clothes). (Gelade 345)

Another reason is that a short story by Cles B. Rambaud, "Lakasa" which he himself translated has the English title "The Wooden Trunk" which is included in Lingka: An Anthology of Iloko Literature in English (1994).

Definitely not one of these possibilities would equal the original polysemic character of the units in the original poems. In effect, choosing one of these possibilities to render the original units in the translations results in the infamous "loss" in translation. However, I came to realize that translating consists of choosing which ones to hold onto and which ones to let go, and oftentimes negotiating between losing and keeping-in a way a form of estrangement, alienation.

It has been my aim, for this particular suite to, "[...] produce a reverberation of the foreign language's work” (150), borrowing from Walter Benjamin. However, pushing on with Newmark, translation is for the reader (128):

A translation is normally written and intended for a target language reader-even if the source language text was written for no reader at all, for noting but its author's pleasure. The translator has to assist his reader. In plain terms, it is usually more important for him to make or indicate the sense of a passage than to funk the issue by rendering it 'correctly'. He may have to explain or transpose allusions, supply reasons, emphasize contrasts. Even if the SL text is generalized and abstracted on the analogy of non-figurative art or has what seems like surrealistic or stochastic interventions, it is his duty to make his version a little more accessible to the reader, to find at least some pattern in non-sense. Styles which are dense and intellectualized may also require assistance from the translator. (128)

Kritika Kultura 28 (2017): -395

(c) Ateneo de Manila University

<http://journals.ateneo.edu/ojs/kk/> 


\section{Works Cited}

Agcaoili, Aurelio S. "Estrangement and Homing in Ilokano Poetics: A Critical Introduction." Rekuerdo/Memento: Estrangement and Homing in Ilokano Poetics. Ed. trans. and with a critical introduction by Aurelio Solver Agcaoili. Iwah/GUMIL Hawaii, 2009. 3-27.

Agcaoili, Aurelio S., ed. Rekuerdo/Memento: Estrangement and Homing in Ilokano Poetics. Ed., trans., and with a critical introduction by Aurelio Solver Agcaoili. Iwah/GUMIL Hawaii, 2009.

Agcaoili, Aurelio S. Kontemporaneo a Diksionario nga Ilokano-Ingles. Undertow, 2012.

Aragon, Roy V. "Awis ti Hulio." Kastoy nga Imbunubonmi Dagiti Balikas: Antolohia Dagiti Daniw Iti Iluko. Eds. Joel Manuel and Ariel Tabag. GUMIL Filipinas, 2010. 72-3.

Benjamin, Walter. “The Translator's Task." Trans. Steven Rendall. TTR: traduction, terminologie, rédaction 10, no. 2, 1997, pp. 151-65. ID Erudit.

Cabie, Honor Blanco, et al., ed. Lingka: An Anthology of Iloko Literature in English. GUMIL Metro Manila, 1994. Print.

Foronda, Marcelino A., Jr. Kutibeng: Philippine Poetry in Iloko, 1621-1971. De La Salle University, 1976.

Gelade, George P. Ilokano-English Dictionary. CICM Missionaries, 1993.

Iloko-English Dictionary (Rev. Andres Carro's Vocabulario Iloco-Español). Trans., augmented and revised by Morice Vanoverbergh. CICM, 1956.

Madulid, Domingo A. A Dictionary of Philippine Plant Names. Vol. I. Makati City: The Bookmark, 2001.

Manuel, Joel B., and Ariel Tabag, eds. Kastoy nga Imbunubonmi Dagiti Balikas: Antolohia Dagiti Daniw Iti Iluko. GUMIL Filipinas, 2010.

Newmark, Peter. Approaches to Translation. Pergamon, 1981.

Pardo de Tavera, T.H. Plantas Medicinales de Filipinas/Medicinal Plants of the Philippines. Makati City: Ayala Foundation, 2000.

Rasing, Mighty C. "Ipapanaw Iti Maikasangapulo a Balay." Kastoy nga Imbunubonmi Dagiti Balikas: Antolohia Dagiti Daniw Iti Iluko. Eds. Joel Manuel and Ariel Tabag. GUMIL Filipinas, 2010. 65-6.

Tabag, Ariel S. “(No) Maysaakon A Sangsangaili." Kastoy nga Imbunubonmi Dagiti Balikas: Antolohia Dagiti Daniw Iti Iluko. Eds. Joel Manuel and Ariel Tabag. GUMIL Filipinas, 2010. 7 .

Tabag, Ariel S. "Superhighway." In Kastoy nga Imbunubonmi Dagiti Balikas: Antolohia Dagiti Daniw Iti Iluko. Eds. Joel B. Manuel and Ariel S. Tabag. GUMIL Filipinas, 2010. 9. 


\section{SUPERHIGHWAY}

Ariel S. Tabag

Nupay adayo nga at-atiddog

Ngem iti agsisipol a bitukami,

Kas iti lapis iti papel

Ti tammudo iti awaymi

Kaykayat dagiti agtutubo

Ti agurnos iti bato, graba ken semento

Ngem ti agmula iti kapitakan-

Kunada a kongkreto ti panagdur-as

Ket agat-daga ti kinakurapay;

Uray bingkol no tumangken,

Tapok met laeng a masayyasayya.

Karemkemenda dagiti sensilio-

Mabsogda, ket ti panagtig-abda iti pirak

Pammati a naparpartak a rumtab

Dagiti angalo a pasdek

Ngem dagiti uong nga agbaribari pay

Kadagiti ansisit.

Dangdanganen laengen ti lugan

Ti nagbaetan ti agtutubo ken nagannak

Kas iti panangkawikawna iti minilmilia

A talon, turod, karayan, bakir ken tangatang

Iti nagbaetan ti bullalayaw iti laud

Ken ti taaw iti daya-

iti daya a lumung-aw dagiti siokoy

a nagimet iti motorsiklo, telebision,

kotse, casino, beach resort, ket iti apagkirem,

agbalinda a balitok iti sakaanan ti bullalayaw; 
Nakaparpartak ti trak

Ngem ikagumaan ti agtutubo ti kumamat

Ket mabati, matallikudan ti kataltalonan

Aglinglingaling, agtengtengngaag ti bambanti

Dina maawatan ti nakaisupadianna

Iti lakay nga agpaspastor: kas iti pagay

Inunaanen dagiti ruot, agur-uraten ti gurong ken kimmot

Saanen a makatakder, saanen a makakamat,

Baybay-anna a sallukoban dagiti pan-aw

Ket in-inut nga agsubli iti daga... 


\section{SUPERHIGHWAY}

Ariel S. Tabag

Although it is much longer

Than our intestines all connected,

Like pencil and paper

Our barrio is a stone throw away;

The youth prefer

To arrange stones, gravel and cement

Than to plant in muddy paddies-

They say that progress is concrete

And poverty smells of earth;

Even clod when it hardens

Is still dust that goes asunder.

They crunch coins-

They get full, and as they burp money

The belief is perpetuated that it is faster to grow

Colossal buildings

Than mushrooms which require to ward off

Dwarves.

As if but a few inches the vehicle traverses

The distance between youth and parent

Like how it coils around the miles and miles

Of fields, hills, rivers, forests, and sky

In between the rainbow in the west

And the ocean in the east-

mermen surface to the east

loaded with motorcycle, television,

cars, casino, beach resort, which in a blink of an eye,

become gold at the end of the rainbow; 
The truck is too fast

But the youth strives to run after it

And the fields get left behind, turned back on;

The scarecrow slowly swaying, nodding,

Does not understand its difference from

The old man tending his flock: like the rice plant

Outgrown by weeds, his legs and behind riddled with veins

Can no longer stand, can no longer keep apace,

He lets the cogon grass cover him

Then slowly returns to the earth...

(Translated from the Ilokano by JL Lazaga) 


\section{IPAPANAW ITI MAIKASANGAPULO A BALAY}

Mighty C. Rasing

Nadadagsen a karton iti abay ti ruangan-

Napapateg a banag a naurnong kadagiti napalabas

A tawen. Ungaongdan

Dagiti estante, aparador, lamisaan.

Nairuaren agraman dagiti karton a di man laeng

Naluktan sipud pay dimtengkami iti daytoy a balay.

Dua a tawen-

A napno ti uneg dagitoy a diding

A naisaad iti abay ti kapilia

Nga awan kampanana.

Dumakkelton dagiti ruot

Iti aglawlaw ti balay. Nataytayagdanton

Ngem dagiti sabong

Ti rosas iti hardin

Iti nagbaetan ti balay a mapanawan

Ken ti kapilia nga awan

kampanana.

Nakatugaw met dagiti mula kadagiti masetera

A nagtubuanda iti sango ti balay

A mapanawan. Inanusanda

Ti nagtubo; ti nagsabong manipud natukkolda

Iti puon a nagtaudanda,

Babaen iti apros ti init, ti digos ti tudo.

Ket ti linnaaw inaldaw a simmarungkar

Tapno agkanna dagiti sabong

A nangted maris iti paraangan

Ti balay.

Ngem ita

maipanawdan, 
mayakar ken maipan iti disso

a dida ammo.

Naunegen ti ramut

Dagiti kayo ti santol ken mangga

A di pay nagbunga. Sumurotda ngata?

Kasano a maipanawda

No dida met makali?

Ket no makalida man, agbiagda

pay ngata iti pakayakaranda a daga?

Dagiti aparador ken bado, ti washing machine ken pridyider,

Dagiti lamisaan ken estante-amin nga alikamen

Addan iti ruar, agur-uray a sipapasnek

Iti maysa manen nga ipapanaw.

Ngem saan pay a daytoy ti maudi

a panagdaliasat

dagitoy a gameng.

Gagangay laeng-

Sumangpet, pumanaw, sumangpet manen

Ket pumanawto met laeng...

Awan sarday a panagakar

Awan sarday a panaggunay

Saankami nga agtalinaed

Iti maymaysa a disso

Iti naunday a panawen

Gagangay laeng!

Maysa manen nga ipapanaw ket inkam sangpetan

Ti sabali a kapilia nga awan

Kampanana ken sabali a balay

A naipatakder iti abayna-

A saanmi a kukua. 


\section{LEAVING THE TENTH HOUSE}

Mighty C. Rasing

Heavy boxes beside the door-

Valuable things amassed throughout

The years. Idle now

Are the shelves, cabinets, tables.

They have been taken out including the box that was never even

Opened since we arrived in this house.

Two years-

Filled the inside of these walls

Built next to the chapel

Without a bell.

The weeds shall soon grow

Around the house. They will reach higher

Than the flowers

Of the roses in the garden

Between the house to be left

And the chapel without

a bell.

While the plants sit on the flowerpots

Where they sprouted in front of the house

That will be left. They persevered

To grow; to bloom since they were cut

From the plant where they arose,

With the gentle touch of the sun, the shower of rain.

And the dew visited every day

To kiss the flowers

That gave color to the surroundings

Of the house.

But now

they will be transported, 
taken away and brought to a place

that they do not know.

The santol and mango trees

Which have not yet borne fruits

Have taken root deeply into the soil. Will they come along?

How will they be transported

If they cannot be dug?

And if they can be dug, will they thrive

in the land where they will be moved?

The cabinets and clothes, the washing machine and the refrigerator,

The tables and shelves-all the things

Are now outside, waiting patiently

For another leaving.

But this shall not be the last

journey

for these treasures.

It is not unusual-

Arrive, leave, arrive again

And shall again leave...

Unending transport

Unceasing movement

We will not stay

In one place

For a long time

That's how it is!

Another leaving and we arrive at

Another chapel without

A bell and another house

Built beside it-

That is not ours.

(Translated from the Ilokano by JL Lazaga)

Kritika Kultura 28 (2017): -395

(c) Ateneo de Manila University

<http://journals.ateneo.edu/ojs/kk/> 


\section{(NO) MAYSAAKON A SANGSANGAILI}

Ariel S. Tabag

Iti panagsublik, natakuatak a naipadagan

Dagiti armas ken prinsipio. Napagpapatasen

Dagiti taltalon, bakir ken turod. Saanen

A natina iti dara dagiti ubbog ngem ti arapaap

Dagiti karayan, mailaklakon kadagiti turista

Kadagiti kalapaw kadagiti sirok ti rangtay.

Naimulan dagiti kanalbuong ket kasla uong

A nagtubon dagiti kapilia. Dagiti agtutubo,

Nagigpildan kadagiti biblia: agsasallupang

Dagiti alleluia-dagiti agduduma a nagan ti dios,

Saan ketdi a bala, dagiti maisirsirig

Iti tunggal maysa ket pakaitan-okan ti mapuntaan.

Nasurotanen dagiti desdes nga agturong

Kadagiti pagadalan. Natakuatandan a saan

A naaladan ti lubong ket adda dagiti nalawa

A tanap a pagdaliasatan-pakateggedan

Iti naisangsangayan a nagan ken gasat

A mangipasdek iti batonlagip ti kinaalibtak.

Saanen a gumilgil-ayab ti bannawag

Ta inadawen dagiti bombilia ti rimatna.

Addan kadagiti estereo dagiti tumatayab-

Iti telebision dagiti alutiit ken kawitan

Ket ti kanito: marukod, makunikon, mabennat,

Maisaluket, magatang, mangirsian, maipalapal...

Napnon iti botika dagiti pispis ken boksit

Espesialti dagiti restauran dagiti karurayan

Natatayagen dagiti sementado nga alad 
Ta nagdalapdapen dagiti atap a lanut

Iti nagbabaetan dagiti dadakkel a balay

Addaan iti bukod a kalsada ti tunggal ridaw.

Imbagak ti papanak ket intudoda ti lakasa:

Ditoy a nabirokak ti tugot ken pagtaengak. 


\section{(IF) I HAVE BECOME A STRANGER}

Ariel S. Tabag

In my return, I discovered that the weapons and principles

Have already been begotten to the earth. The fields, forests and hills

Have already been levelled. The springs

Are no longer dyed in blood, but the dream

Of the rivers are already being sold to tourists

In the huts under the bridge.

The explosions have already been planted and like mushroom

Chapels have sprouted. The youth

Now carry bibles under their arms: here and there

The alleluias-the different names of god,

And not bullets, are aimed

At each other and would exalt whoever is hit.

The trails have now been trodden which lead

To schools. They have already discovered that

The world is not fenced and there are wide

Plains to travel-where one can work and earn

A special name and a luck

To build one's own memorial of zeal.

The dawn no longer blazes

For bulbs have taken its brilliance.

Birds and butterflies are now in stereos-

Lizards and roosters up on the television

And the moment: measurable, rewindable, stretchable,

Can be tucked, bought, grinned at, hurled about...

Drugstores have already filled temples and bellies

Yellow-legged chickens are a specialty in restaurants

Concrete cement fences are now high 
For wild vines have already crept

Between the big houses

Each door with its own road.

I told where I am to go and they pointed at the old wooden trunk:

Here I found my home and traces of the past.

(Translated from the Ilokano by JL Lazaga)

Kritika Kultura 28 (2017): -395

(c) Ateneo de Manila University

<http://journals.ateneo.edu/ojs/kk/> 


\section{AWIS TI HULIO}

Roy V. Aragon

Sumaranta ti lagip kas i'tay isasanikar iti masay-up a sayamusom ti alisuaso ti kattempla a kape a barako.

Wenno iti alingasaw ti kaggao nga innapuy.

Wenno iti ayamuom ti dinengdeng no kasta a panagluluto iti malem. Uminakbay, umadiwara, sumken ken sumnek kas iti idadateng iti Hulio ti bang-i ken sabeng ti tudo, littugaw, dagudog, ken uray pay 'tay nagtagibanglo a pas-eng ken langsi ti masansan a tumabbiraw a bagyo.

Isu a dim' kunkunaen a dim' ammo ti awis ti makalagip.

Kasano koma ngamin, aya, a maiddepko pay ti darang ken dadang ti ginaburam iti dapo a beggang iti dapogan?

Kunak kenka: awan sapri, awan tedted a makasebseb.

Darangidangan latta dagiti sinibbolta a papaya a mula ti akimmula, nga inta idi limed a sinuksukaan. Kasta met dagidi apaglabanag a sarguelas, lomboy ken bugnay nga inta inyas-asin ken kinulkulog.

Kunam kadi nga uray malapgis iti kalendario ti kada agtrenta'y uno a Hulio ket regkasenka metten iti ulimek ti naidalingiding, malinlinay nga innapuy a naikadkad iti dalikan?

Dimo kunaen: burasen ti allawig dagiti manggak a maraitlog ket diak namnamaen ti maipaluom iti kuribot wenno garong. Nga anusak laengen a siguden a sigaman dagiti linuom ti init. 
Kunak kenka: diak almanan, uray ita, ti naluom. Sinigudta idi iti umuna a lawas ti tunggal Hulio dagiti awan pay gunnotna a bunga. Gusgustom idi ken gusgustok nga imbugbugguong. Kaykayatta idi a paglanglangan ti nagangganus, naal-alsem. Dim' kayat ket ti makutkuton, kaykayatam ti agkatkatay.

Ti ammok, agtubtubbog latta met ti nakemmo a manglaglagip.

Nasken kadi pay nga innak ita binsaen amin nga idukit?

Ket wen, sibibiag pay daydi puon ti mansanita a nagtubo iti kadaklan ti narba ken nagpanawan a balay. Kasla la ubing idi nga akimpasmok. Ulienta dagiti nalabbasit a nagbabassit sa pagbingayanta a saggaysaen nga imulsit. Sa katkatawaanta dagiti umassi-assibay a sitsitik ta awanen nabagida a sagpipirit a sam-it.

Hulio ket adu pay dagiti tartarubong ti kamotig nga inta kalien. Adda latta manen natangkenan a dippig a saba nga inta tebbaen. Di maibus dagiti niog nga innak itinnag, buongen ken igaden.

Adda latta pay umanay a tagapulot, asukar lattan no isut' nasken.

Addan iti lilidduokam ti gusod, addan iti barukongmo ti guyod. 


\section{INVITATION OF JULY}

Roy V. Aragon

Memory nimbles like the brisking of the smell of the scent of vapor of freshly made black coffee.

Or the steam of rice newly drawn out of the pot.

Or the aroma of dinengdeng during cooking time

in the afternoon. Diffusing, spreading, it moves and penetrates

like the arrival in July of the sweet rustic stench of rain,

the breeze, the northeast wind, and even the fragranced

stink and putrid of storm that frequently intrudes.

So do not say that you do not know the summons of memory.

How could I even yet put out the blaze

and heat of the ember in the hearth which you have buried in ashes?

I tell you: not a sprinkle, not a drip can extinguish.

The papaya fruits which we plucked with a bamboo pole from the tree of whoever planted it, which we secretly dipped in vinegar, are yet to ripen.

So are the still maturing sarguelas, lomboy

and bugnay which we used to sprinkle with salt and shook in the hollow of plate and bowl.

Did you think that if the page is torn from the calendar

every thirty-first of July, that I will also shed you off

into the silence of rice being waiting to be cooked thoroughly

which is placed against the embers on the furnace of the open earthen stove?

Don't say: the whirlwind will pluck my mangoes while they are still the size of eggs and cannot hope for some to ripen in any of the bamboo baskets.

That I should just once and for all pick and be content with those ripened by the sun. 
I tell you: I do not crave, even now, for the ripe.

We gathered early ahead in each first week of July

the immature fruits before. You used to like it very much as well as I very much did like to dip them in bugguong. We used to be fond of sitting together at the table sharing the young and green, sour fruits.

You didn't like being swarmed with ants, you liked drooling.

What I know is, your thoughts still salivate in remembering.

Do I still need to enumerate everything and recall?

But of course, the mansanita tree that grew in the main chamber of the house that toppled and was deserted still thrives. It used to be like a child that claimed its own cache. We climbed for the tiny red fruits then we shared in sucking and spitting out the peelings one by one. Then we laughed at those small blackbirds flying around for they were left nothing of the pinch-sized sweet.

July it is and there are still a lot of sweet potato shoots we will dig. There would still be a bunch of matured dippig banana fruits we will cut down.

We will not run out of coconut fruits which I will pick and drop, break open and scrape off.

There is always enough traditionally-processed sugar, or the refined one if needs be.

The mortar is by the call of your appetite, your chest moves you to pull it.

(Translated from the Ilokano by JL Lazaga) 